\title{
Maturation of early-ripening mandarin as affected by scion and rootstock cultivars in western Santa Catarina, Brazil ${ }^{1}$
}

\author{
Eduardo Cesar Brugnara ${ }^{*}$ (D) \\ $10.1590 / 0034-737 X 201966040002$
}

\begin{abstract}
In Santa Catarina, Brazil, 'Satsuma Okitsu' and the 'common mandarin' (Citrus deliciosa Ten.) are the widely known mandarin varieties harvested earlier than 'Ponkan'. This study analyzed and compared the maturation evolution of early maturing mandarins in two rootstocks. The experiment had as treatments combinations of the scion cultivars SCS458 Osvino, Clemenules, Satsuma Okitsu and Mexirica do Rio IAC and the rootstocks 'Swingle' and 'IAC 387 Carrizo'. Fruit were sampled during ripening to evaluate soluble solids (SS), total acidity (TA), ratio (SS/TA), juice content and skin color (CIE Lab parameters and color index - CI). Treatments were compared by analysis of variance and linear and nonlinear modeling. Scions significantly affected the evaluated variables, but no rootstock effect was found. 'SCS458 Osvino' showed earlier ratio and, mainly, CI, but its juice content was low in part of the period. 'Satsuma Okitsu' and 'Clemenules' presented, early, higher CI and ratio than 'Mexirica do Rio IAC'. In conclusion, the cultivars SCS458 Osvino, Satsuma Okitsu and Clemenules are more precocious in maturation compared to 'Mexirica do Rio IAC', and the first is the most precocious in peel maturation.
\end{abstract}

Keywords: citrus; acidity; soluble solids; color; C.I.E.-Lab.

\section{INTRODUCTION}

Brazil harvests around 50 thousand hectares of mandarin orchards (here included satsumas, mandarins and clementines). Twenty one thousand are found in southern states. Cerro Azul (Paraná) and Montenegro (Rio Grande do Sul) are the main producer micro regions. In Santa Catarina state, most orchards are located in the micro regions of Rio do Sul and Concórdia (Instituto Brasileiro de Geografia e Estatística - IBGE, 2018).

Citrus ripening is determined based on four main characteristics: juice soluble solids content (SS) positively correlated with sugar content, mainly fructose, glucose and sucrose; juice titratable acidity (TA) - which is conferred mainly by citrate and malate; peel color green given by chlorophyll and yellow-orange by carotenoids; and juice content, what is expected to be more than $35 \%$. During maturation, SS rises, TA is reduced, green peel gets yellow or orange (Albertini et al., 2006; Manera et al., 2013; Khosravi et al., 2015) and juiciness rises but tends to fall in the end of maturation. The division of SS by TA results in ripening index (RI), or ratio, which is the more widely used parameter to determine table citrus harvesting time.

In Santa Catarina, mandarin harvest is concentrated from April to August, mainly as consequence of a restrict cultivar composition. No data are available on the amount of fruit harvested or commercialized by cultivar, but it is known when 'Ponkan' (Citrus reticulate Blanco) gets ripe, prices go significantly depressed. So, producing earlierripening cultivars can be an opportunity for growers to attain higher profits. In the west, 'Satsuma Okitsu' $(C$.

Submitted on February 19 $9^{\text {th }}, 2019$ and accepted on August 08 ${ }^{\text {th }}, 2019$.

${ }^{1}$ Supported by Conselho Nacional de Desenvolvimento Científico e Tecnológico, Fundação de Amparo à Pesquisa e Inovação do Estado de Santa Catarina and Financiadora de Estudos e Projetos.

${ }^{2}$ Empresa de Pesquisa Agropecuária e Extensão Rural de Santa Catarina, Centro de Pesquisa para Agricultura Familiar, Chapecó, Santa Catarina, Brazil, eduardobrugnara@epagri.sc.gov.br *Corresponding author: eduardobrugnara@epagri.sc.gov.br 
unshiu Marc.) and 'Mexirica do Rio IAC' or "common mandarin" ( $C$. deliciosa $T e n$.$) are the only widely grown$ and known varieties which can be harvested before 'Ponkan', main market cultivar (Koller \& Soprano, 2013). Recently, some early-maturing clementine (C. clementina Hort. ex Tan.) varieties aroused the interest for cultivation, and a new cultivar of $C$. unshiu - 'SCS458 Osvino', was released, and it is considered more precocious than 'Satsuma Okitsu' based in preliminary data obtained in eastern Santa Catarina (Maro et al., 2018).

Those early-maturing mandarins are especially interesting for cultivation in warm regions, because the higher the thermal sum, the earlier the harvest (Stenzel et $a l ., 2006)$. In western Santa Catarina, there are lands with elevation from 300 to $600 \mathrm{~m}$, under a Köppen Cfa climate, where temperatures are relatively high, ensuring a precocious maturation of mandarins. However, in such condition, the peel of early harvest fruit tends to delay in acquiring yellow/orange color, since loss of chlorophyll and rise of carotenoids are dependent of low minimum air temperatures (Manera et al., 2013).

The objective of this research was to analyze and compare the ripening evolution of alternative, earlymaturing mandarin cultivars budded in 'Swinlge' and 'IAC 387 Carrizo’ rootstocks.

\section{MATERIAL AND METHODS}

Evaluated fruit were taken from an experiment located in Águas Frias municipality, Santa Catarina state, in Chapecó river valley $\left(26.84406^{\circ} \mathrm{S}, 52.868725^{\circ} \mathrm{O}, 378 \mathrm{~m}\right.$ elevation). An split-plot experiment was designed in random blocks, having the scion cultivars the satsumas 'SCS458 Osvino', 'Satsuma Okitsu' (C. unshiu Marc.), the clementine 'Clemenules' (C. clementina Hort. ex Tan.) and the willow leaf mandarin 'Mexirica do Rio IAC' (C. deliciosa Ten.) as main treatment, and in subplots the rootstocks 'Swingle' C. paradisi Mac. x Poncirus trifoliata (L.) Raf., and 'IAC 387 Carrizo' - C. sinensis (L.) Osb. x P. trifoliata (L.) Raf.]. Trees were planted November 2010, spaced $7 \times 3 \mathrm{~m}$. Fertilization consisted in manure supply.

In 2016 and 2017 harvest seasons, when the orchard was 7 and 8 years old, fruit were sampled from February to June, depending on the expected ripening time for each cultivar and sensorial aspects of fruit (taste, color, size and firmness). Each sample (one per subplot) was composed by 12 fruit collected near $1.5 \mathrm{~m}$ height from the canopy's periphery. Peel color was accessed in two points at the equatorial line of each fruit (the greenest and the more orange/yellow) using a color meter (Konika-Minolta CR-400). The parameters $L, a$ and $b$ from C.I.E.-Lab color space were averaged and used to calculate the color index $\left(\mathrm{CI}=1000 * a / L^{*} b\right)($ Jimenez-Cuesta et al., 1981). The same fruit were weighted and submitted to juice extraction for determination of juice content, soluble solid content (SS, determined by refractometry) and titrable acidity (TA, by $\mathrm{NaOH}$ titration until $\mathrm{pH}$ 8). Than RI was calculated dividing SS by TA.

Once each year (March 28, 2016 and April 04, 2017) all scions were evaluated at same date for RI, juice content and CI, such data were submitted to an analysis of variance and Tukey test. Linear and non-linear models were fitted having as independent variable the number of days after December 31 , i.e. January $1^{\text {st }}$ is day 0 , correspondent to harvest date. The models tested were first and second grade linear models, the nonlinear models Monomolecular $\left[\mathrm{y}=A_{u}-\left(A_{u}-y_{0}\right) * \exp ^{(-r * x)}\right]$ and Mitscherlich [ $\mathrm{y}=A_{u} *(1-$ $\left.\exp ^{\wedge}\left(\log (1-0.99) *\left(\left(\mathrm{x}-b_{3}\right) /\left(b_{2}-b_{3}\right)\right)\right)\right]$, both reparametrized by Zeviani (2013), where $A_{u}$ is the upper asymptote, $y_{0}$ is the intercept, $r$ is a rate of increment in $\mathrm{y}, b_{2}$ is the number of days necessary for reaching $99 \%$ of $A_{u}, b_{3}$ controls the function's shape, $\mathrm{x}$ is time and $\mathrm{y}$ response variable; and, once some data (y) were expected to grow from negative to positive values, it was tested a two-asymptote logistic model $\mathrm{y}=A_{l}+\left(\left(A_{u}-A_{l}\right) /\left(1+(\mathrm{x} / I)^{\wedge}-H\right)\right.$, where $A_{l}$ is the lower asymptote, $A_{u}$ is the upper asymptote, $I$ is the inflexion point in ordinate axis, $H$ is the hill of the curve, $\mathrm{x}$ is the time and $y$ the response variable. The best-fitting model for each treatment and season was selected based the minor Akaike information criterion (AIC). Treatments with same model fitted were compared observing its $95 \%$ confidence intervals for the model parameter estimates. All analyses were performed with R (R Core Team, 2018), amended with "minpack.lm” (Elzhov et al., 2016).

Data on mean air temperature registered in the nearest (in distance and elevation) weather station (Maravilha municipality) were cordially provided by the Centro de Informações de Recursos Ambientais e de Hidrometeorologia de Santa Catarina (Epagri/CIRAM, Brazil) (Figure 1).

\section{RESULTS AND DISCUSSION}

Following the variance analysis for variables measured at same date each season, no significant difference was observed between rootstocks neither significant scion $\mathrm{x}$ rootstocks interaction. However, all variables analyzed were affected by scions (Table 1).

When comparing models fitted for RI and CI with two rootstocks inside each scion cultivar, no difference was found since confidence intervals for model parameters were coincident, which corroborates the analysis of variance. Because of that, further analyses were performed with two rootstocks combined. In some cases, for a same scion cultivar the models fitted in two seasons were different (Table 2 and 3 ). 


\section{Juice properties}

Observations on SS and TA are presented in Figure 2. 'Mexirica do Rio IAC' and 'Clemenules' reached higher values of SS than the Satsumas 'Satsuma Okitsu' and 'SCS458 Osvino' both seasons. In addition, for both Satsumas SS varied little along the period considered. 'Clemenules' showed higher values of SS than all others in both seasons. The four scions were more alike in range of TA than SS (Figure 2). However, variation in 'Clemenules' juice along the time was smaller. Juice of 'Mexirica do Rio IAC' showed higher SS, but in the beginning of the season TA was higher too, resulting lower RI.

In 2016, RI of 'Satsuma Okitsu' and 'Clemenules' grew similarly over time (Figure 3 ) with no significant difference (Table 2). On the other hand, the models fitted to 'Mexirica do Rio IAC' and 'SCS458 Osvino' were monomolecular and logistic. In 2017, monomolecular models fitted better to 'SCS458 Osvino', 'Satsuma Okitsu' and 'Clemenules' RI evolution with no difference in the parameters (Table 2). The response of 'Mexirica do Rio IAC' was better explained by a first degree linear equation. Juice of 'Clemenules' presented reduction of RI at the last evaluation, characterized by a quadratic model, which was due to a decrease in SS (Figure 2). When compared at same day, 'Mexirica do Rio IAC' presented a lower RI than the other three treatments (Table 1).

\section{Juice content}

All scions produced fruit with adequate juice content (> 35\%) in some part of the evaluation period (Figure 2). 'Satsuma Okitsu', sampled until near 90 days, always had fruits adequate in juice. When all cultivars were sampled the same day (Table 1), 'Satsuma Okitsu' was significantly juicier than others at both seasons. 'Clemenules' the two years and 'Mexirica do Rio IAC' at 2017 had less than $35 \%$ at the end of season (Figure 2). Juice content of 'SCS458 Osvino' was more limiting, especially at 2016, when just two intermediate samples resulted in adequate juice content.

\section{Peel color}

During almost the entire evaluation period, values measured for $L, a$ and $b$ grew all scions and seasons (Figure 4), but earlier in 'SCS458 Osvino', followed by 'Satsuma Okitsu', 'Clemenules' and 'Mexirica do Rio IAC'. Despite differences in sampling period among scion cultivars, values of $a$ (which means more red and less green) reached higher magnitudes in 'Mexirica do Rio IAC'

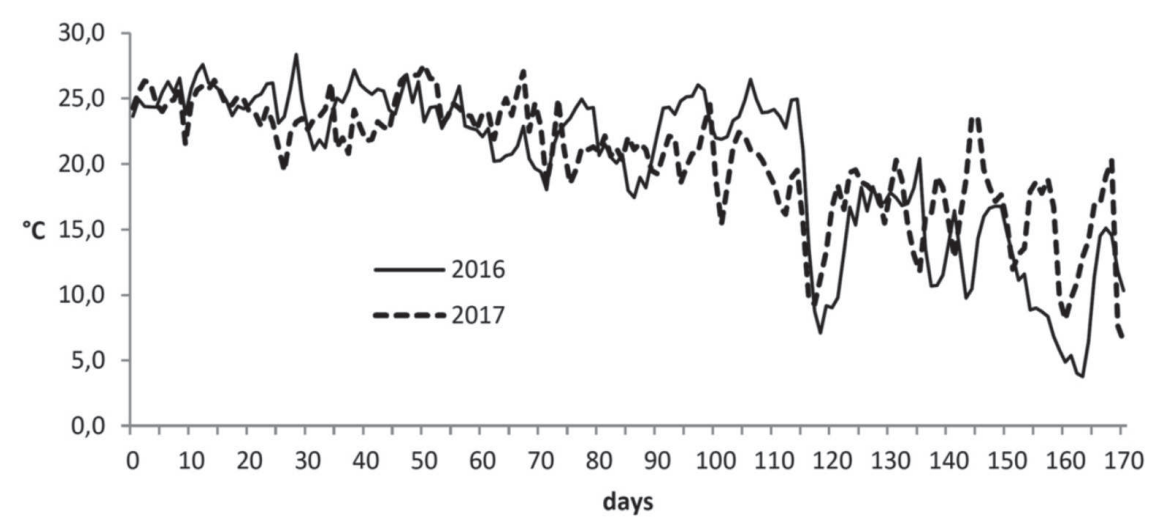

Figure 1: Mean air temperature observed in Maravilha weather station (elevation $=573 \mathrm{~m}$, approximately $30 \mathrm{~km}$ far) in the first semester of 2016 and 2017. (Data cordially provided by Epagri/CIRAM).

Table 1: Comparison of mandarin scion cultivars (mean of two rootstocks) regarding ripening index (RI) of the juice, juice content and peel color index (CI), in two harvest seasons

\begin{tabular}{|c|c|c|c|c|c|c|}
\hline \multirow[b]{2}{*}{$p$ value } & \multicolumn{3}{|c|}{$88^{\circ}$ day, 2016} & \multicolumn{3}{|c|}{$94^{\circ}$ day, 2017} \\
\hline & RI & Juice (\%) & CI & RI & Juice (\%) & CI \\
\hline scion & $<0001$ & $<0.001$ & $<0.001$ & $<0.001$ & 0.002 & $<0.001$ \\
\hline rootstock & 0.72 & 0.29 & 0.06 & 0.98 & 0.79 & 0.59 \\
\hline interaction & 0.66 & 0.70 & 0.11 & 0.59 & 0.40 & 0.31 \\
\hline Scion & \multicolumn{6}{|c|}{ Tukey comparison ${ }^{(1)}$} \\
\hline $\begin{array}{l}\text { SCS458 Osvino } \\
\text {. }\end{array}$ & $12.31 \mathrm{a}$ & $33.2 \mathrm{c}$ & $-0.79 a$ & $12.0 \mathrm{a}$ & $31.7 \mathrm{c}$ & $1.6 \mathrm{a}$ \\
\hline Satsuma Okitsu & $12.77 \mathrm{a}$ & $43.7 \mathrm{a}$ & $-1.37 \mathrm{a}$ & $12.3 \mathrm{a}$ & $47.5 \mathrm{a}$ & $-1.0 b$ \\
\hline Clemenules & $13.32 \mathrm{a}$ & $39.8 b$ & $-9.78 b$ & $12.8 \mathrm{a}$ & $40.7 b$ & $-11.9 \mathrm{c}$ \\
\hline Mexirica do Rio IAC & $9.00 \mathrm{~b}$ & $41.3 b$ & $-14.17 \mathrm{c}$ & $7.7 .8 \mathrm{~b}$ & $39,4 b c$ & $-15.8 d$ \\
\hline
\end{tabular}

\footnotetext{
${ }^{(1)}$ Average of two rootstocks. Means followed by the same letter inside each season do not differ statistically (Tukey test, $\alpha=0.05$ ).
} 
and, mainly, in 'Clemenules'. As observed for RI, CI evolution pattern varied among scions and season (Table 3). First grade linear models were fitted to CI of 'SCS458 Osvino' both season, while for 'Satsuma Okitsu' logistic nonlinear models were more adequate. 'Mexirica do Rio
IAC' and 'Clemenules' showed different evolution patterns among seasons (Figure 3). Inside each season, the second grade model (2016) and logistic (2017) differed significantly between 'Mexirica do Rio IAC' and 'Clemenules' (Table 3), which means the latter is more precocious (Figure 3).

Table 2: Linear and non-linear models adjusted to the response of four scions (mean of two rootstocks) ripening index (y) to the time (x) along 2016 and 2017 harvest season. Parameter estimates are followed by the limits of its 95\% confidence interval

\begin{tabular}{|c|c|c|}
\hline Scion & 2016 & 2017 \\
\hline \multirow[t]{2}{*}{ Mexirica do Rio IAC } & Monomolecular $^{(1)}-\mathbf{R}^{2}=0.93$ & First grade model ${ }^{(2)}-\mathbf{R}^{2}=0.92$ \\
\hline & $\begin{array}{l}A_{u}=18.58(16.59 ; 20.56) \\
y_{0}=-109(-252 ; 34.1) \\
r=0.03(0.015 ; 0.044)\end{array}$ & $\begin{array}{l}a=-7.23(-9.62 ;-4.84) \\
b=0.16(0.14 ; 0.18)\end{array}$ \\
\hline \multirow[t]{2}{*}{ Osvino } & $\operatorname{Logistic}^{(3)}-R^{2}=0.89$ & Monomolecular $-\mathrm{R}^{2}=\mathbf{0 . 7 9}$ \\
\hline & $\begin{array}{l}A_{l}=6.38(4.81 ; 7.94) \\
A_{u}=13.50(11.34 ; 15.67) \\
I=58.61(50.79 ; 66.42) \\
H=6.03(0.66 ; 11.39)\end{array}$ & $\begin{array}{l}A_{u}=13.91(9.16 ; 18.65) \\
y_{0}=-3.84(-15.60 ; 7.91) \\
r=0.023(-0.002 ; 0.048)\end{array}$ \\
\hline \multirow[t]{2}{*}{ Satsuma Okitsu } & Second grade model ${ }^{(4)}-R^{2}=0.78$ & Monomolecular $-\mathbf{R}^{2}=0.91$ \\
\hline & $\begin{array}{l}a=-4.9(-8.66 ;-1.14) \\
b=0.38(0.25 ; 0.51) \\
c=-19 \mathrm{e}^{-4}\left(-30 \mathrm{e}^{-4} ;-9 \mathrm{e}^{-4}\right)\end{array}$ & $\begin{array}{l}A_{u}=15.10(11.41 ; 18.8) \\
y_{0}=-2.89(-8.31 ; 2.52) \\
r=175 \mathrm{e}^{-4}\left(58 \mathrm{e}^{-4} ; 293 \mathrm{e}^{-4}\right)\end{array}$ \\
\hline \multirow[t]{2}{*}{ Clemenules } & Second grade model ${ }^{(4)}-R^{2}=0.84$ & Monomolecular $-\mathrm{R}^{2}=\mathbf{0 . 8 7}$ \\
\hline & $\begin{array}{l}a=-5.76(-11.49 ;-0.03) \\
b=0.36(0.24 ; 0.48) \\
c=-15 \mathrm{e}^{-4}\left(-21 \mathrm{e}^{-4} ;-9 \mathrm{e}^{-4}\right)\end{array}$ & $\begin{array}{l}A_{u}=17.38(13.53 ; 21.23) \\
\left.y_{0}=-4.93(-20.97 ; 11.1)^{4}\right) \\
r=0.016\left(15 \mathrm{e}^{-4} ; 300 \mathrm{e}^{-}\right.\end{array}$ \\
\hline
\end{tabular}

Table 3: Linear and non-linear models adjusted to the response of four scions (mean of two rootstocks) fruit peel color index (y) to the time (x) along 2016 and 2017 harvest season. Parameter estimates are followed by the limits of its $95 \%$ confidence interval

\begin{tabular}{|c|c|c|}
\hline & 2016 & 2017 \\
\hline \multirow[t]{2}{*}{ Mexirica do Rio IAC } & Second grade model ${ }^{(1)}-R^{2}=0.97$ & Logistic $^{(2)}-\mathbf{R}^{2}=0.99$ \\
\hline & $\begin{array}{l}a=-53.3(-68.29 ;-38.42) \\
b=0.54(0.28 ; 0.79) \\
c=-105 \mathrm{e}^{-5}\left(-211 \mathrm{e}^{-5} ; 0.6 \mathrm{e}^{-5}\right)\end{array}$ & $\begin{array}{l}A_{l}=-15.9(-17.16 ;-16.64) \\
A_{u}=4.58(3.41 ; 5.76) \\
I=118.7(116.95 ; 120.42) \\
H=12.67(10.09 ; 15.25)\end{array}$ \\
\hline \multirow[t]{2}{*}{ Osvino } & First grade model $^{(3)}-\mathbf{R}^{2}=\mathbf{0 . 8 9}$ & First grade model $-\mathbf{R}^{2}=\mathbf{0 . 9}$ \\
\hline & $\begin{array}{l}a=-18.55(-20.49 ;-16.62) \\
b=0.2(0.17 ; 0.23)\end{array}$ & $\begin{array}{l}a=-18,24(-20.02 ;-16.47) \\
b=0.21(0.18 ; 0.24)\end{array}$ \\
\hline Satsuma & Logistic $-\mathbf{R}^{2}=0.97$ & Logistic $-\mathbf{R}^{2}=0.98$ \\
\hline Okitsu & $\begin{array}{l}A_{l}=-13.58(-14.51 ;-12.64) \\
A_{u}=-0.11(2.42 ; 2.21) \\
I=68.97(65.17 ; 72.76) \\
H=9.29(5.4 ; 13.18)\end{array}$ & $\begin{array}{l}A_{l}=-14.49(-15.83 ;-13.16) \\
A_{u}=10.19(0.4 ; 19.97) \\
I=91.38(73.64 ; 109.11) \\
H=4.05(2.41 ; 5.69)\end{array}$ \\
\hline \multirow[t]{2}{*}{ Clemenules } & Second grade model $-\mathbf{R}^{2}=\mathbf{0 . 9 8}$ & Logistic $-\mathbf{R}^{2}=0,99$ \\
\hline & $\begin{array}{l}a=-28.5(-36.03 ;-21.04) \\
b=0.14(-0.016 ; 0.31) \\
c=7.86^{-4}\left(-0.49 \mathrm{e}^{-4} ; 16.2 \mathrm{e}^{-4}\right)\end{array}$ & $\begin{array}{l}A_{l}=-17.07(-18.28 ;-15.87) \\
A_{u}=14,3(10.7 ; 17.89) \\
I=118.05(114.36 ; 121.74) \\
H=7,78(6.15 ; 9.4)\end{array}$ \\
\hline
\end{tabular}

${ }^{(1)->} \mathrm{y}=a+b \mathrm{x}+c \mathrm{x}^{2} ;{ }^{(2)} \mathrm{y}=A_{l}+\left(\left(A_{u}-A_{l}\right) /\left(1+(\mathrm{x} / I)^{\wedge}-H\right)\right) ;{ }^{(3)} \mathrm{y}=a+b \mathrm{x}$

Rev. Ceres, Viçosa, v. 66, n.4, p. 249-256, jul/aug, 2019 
In the comparison performed with all scions at same day, CI was significantly higher in both Satsumas than 'Mexirica do Rio IAC' and 'Clemenules' (Table 1). Furthermore, in 2017, 'SCS458' Osvino' had yellower peel than 'Satsuma Okitsu'. In addition, 'Clemenules' showed more peel maturation precocity than 'Mexirica do Rio IAC'.

\section{Discussion}

In the range of time considered here, it is possible to state that 'SCS458 Osvino' and 'Satsuma Okitsu' depend mainly on loss of acidity for reaching commercial maturing. Meanwhile, for 'Clemenules' the increase in SS is more important than loss of AT. Growing trend in SS and RI and decreasing in TA are well known. From blooming to end of ripening, SS of $C$. sinensis responded positively and TA negatively to degree-days accumulation in a quadratic pattern (Stenzel et al., 2006), what explain the evolution observed in this work if considered the short period evaluated, which started some months after bloom.

The values of SS measured for 'Satsuma Okitsu' are lower compared to observation in Turkey $\left(9.2^{\circ} \mathrm{Brix}\right)$ at late September (Yildiz \& Kaplankiran, 2018), equivalent to late March in Brazil, and evaluations at March and February in Londrina (Tazima et al., 2013) and Paranavaí (Tazima et al., 2014), Brazil. It is possible that climate differences are responsible for that discordance, since Londrina and Paranavaí are under hotter climate, what favors SS accumulation.

Harvesting time is difficult to determinate since each market demands a different maturation score. In South Brazil, the minimum RI for harvesting is 8.0 (Koller, 1994). Using the models, it was estimated that 'SCS458 Osvino', 'Satsuma Okitsu' and 'Clemenules' reached juice maturity the $48^{\circ}, 48^{\circ}$ and $44^{\circ}$ day in 2016 and $48^{\circ}, 54^{\circ}$ and $55^{\circ}$ in 2017 , respectively, without any significant difference. Over time, RI of the three tended to keep the same, resulting in absence of difference in evaluations performed around 90-100 days (Table 1). Meanwhile, 'Mexirica do Rio IAC' reached RI equal to 8.0 on the $83^{\text {rd }}$ and $96^{\text {th }}$ days in 2016 and 2017, respectively, which represents 39 to 48 days of delay in relation to the others.

Based on the models, CI of 'Satsuma Okitsu' was estimated to be 3.8 to 5 CI-points lower than of 'SCS458 Osvino' from 45 to 55 days. Since previous information states 'Satsuma Okitsu' is the first mandarin to be harvested in Brazil (Schwarz, 2009), these results qualify 'SCS458 Osvino' as the earlier-ripening mandarin in the country, having as main advantage the peel color. Despite Satsumas capacity to reach orange-red coloration by accumulation of carotenoids like monol, diol, diepoxide
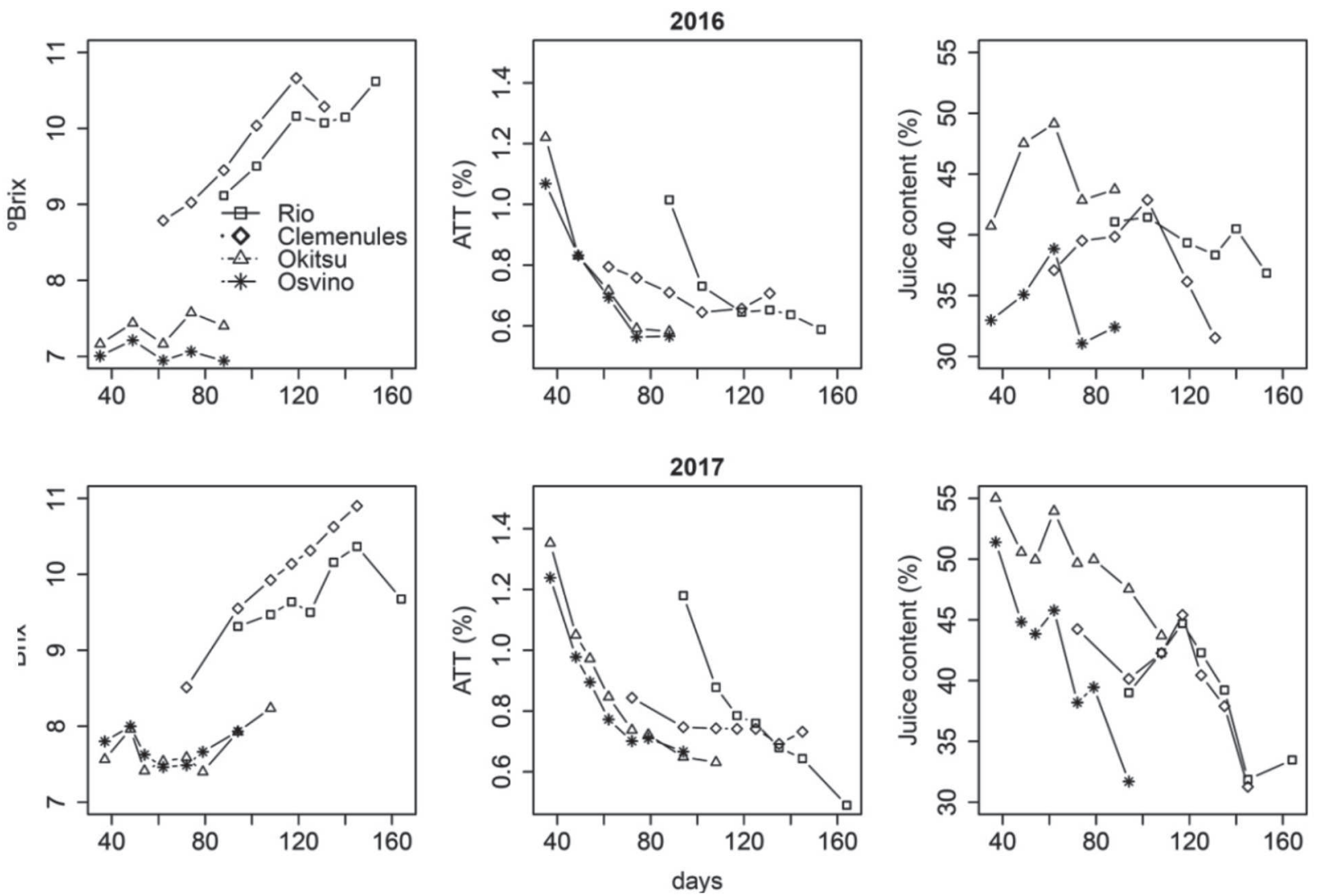

Figure 2: Temporal evolution of soluble solids (SS) and titrable acidity (TA) in the juice and fruit juice content of four mandarin cultivars in the seasons 2016 and 2017 (mean of two rootstocks). Rio = Mexirica do Rio IAC; Okitsu = Satsuma Okitsu; Osvino = SCS458 Osvino. 
and diol monoepoxide (Daito, 1986), the magnitudes reached by the coordinate $a$ from the C.I.E.-Lab system are in the range of green, excepting the last evaluation in 2017. It happened in part because the fruit had been exposed to warmer temperatures until the sampling compared to the days ahead (Figure 1), and low temperatures are negatively correlated to $a$ (Manera $e t$ al., 2013).

Some limitations of 'SCS458 Osvino' have to be considered: around 60-80 days its juice content fell under $35 \%$, what is a minimum value for marketing mandarins. Brugnara (2017) observed that 'SCS458 Osvino' produced big size fruits (averaging 163g), what can partially explain the poor juiciness (Sharma et al., 2006). Late harvest of 'Clemenules' and 'Satsuma Okitsu' in Minas Gerais, Brazil, resulted in high granulation (reduced juiciness inside vesicles) incidence (Santos et al., 2010), what agrees with the trend of reduction in juice of all scions studied here.

Juice content of 'Satsuma Okitsu' was the highest, what agrees with previous findings (Yildiz \&
Kaplankiran, 2018). Means were similar to the observations of Tazima et al. (2013), who measured 44 to $47 \%$ of juice in fruits harvested in Londrina, in March. The same authors corroborate the present observation on SS, TA and RI.

Regarding RI, 'Clemenules' was similar to the Satsumas at beginning of samplings. The similarity of 'Satsuma Okitsu' and 'Clemenules' was previously reported by Santos et al. (2010) at late season (June). However, 'Clemenules' showed higher absolute values of SS and TA, which means its juice is superior in quality besides having same RI. So the limitation to starting to harvest 'Clemenules' relied on its peel color, which turned from green to yellow/orange later compared to the Satsumas. On the other hand, 'Clemenules' had earlier juice and peel maturation compared to 'Mexirica do Rio IAC' and showed the highest SS content. So, it is supposed that, among the scion cultivars tested here, 'Clemenules' juice would be well accepted by the consumer. The values observed in this work for SS and
2016

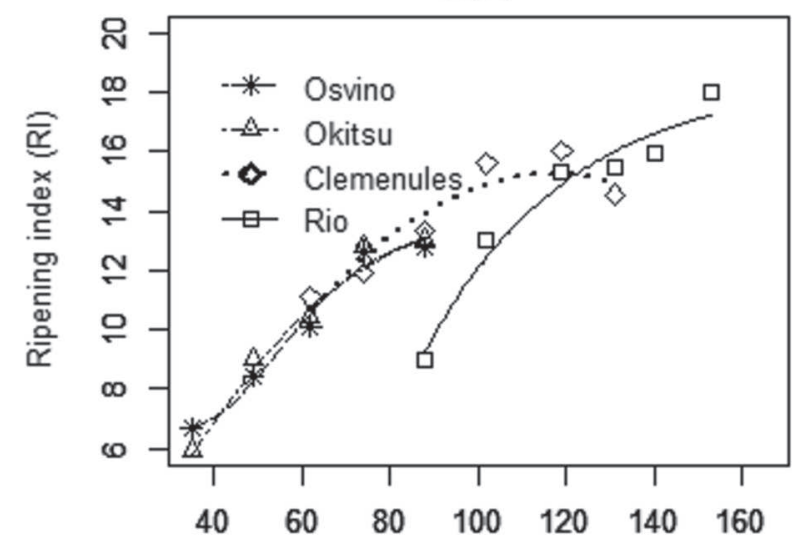

2016

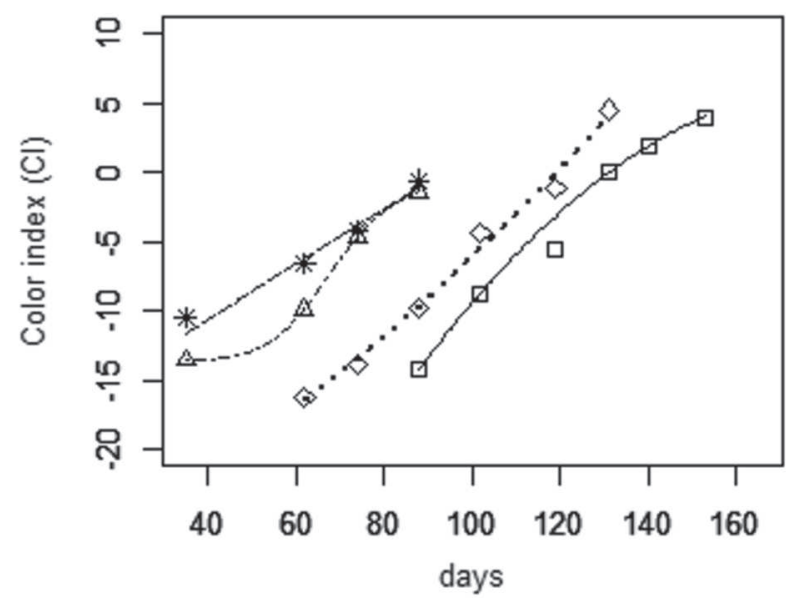

2017

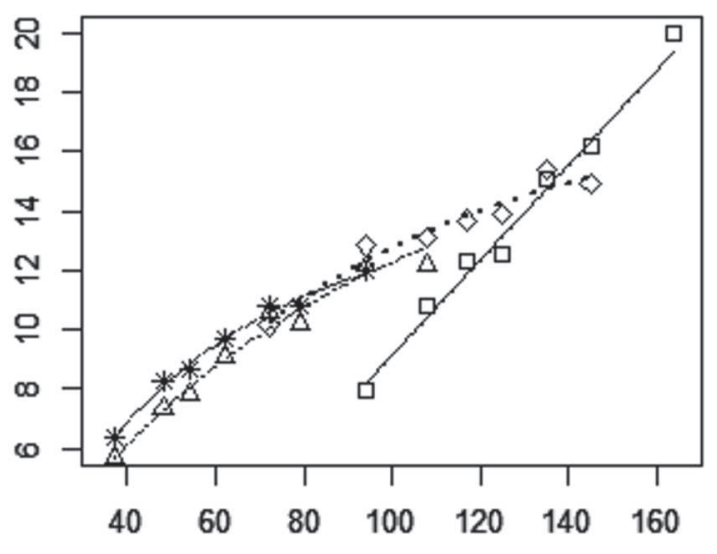

2017

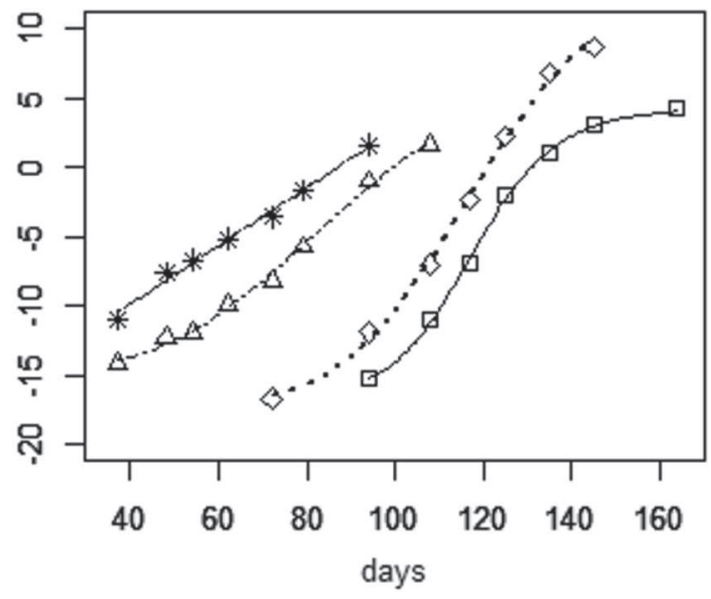

Figure 3: Graphical representation of the models adjusted to the temporal evolution of juice ripening index (RI) and peel color index of four mandarin cultivars in the seasons 2016 and 2017 (mean of two rootstocks). Rio = Mexirica do Rio IAC; Okitsu = Satsuma Okitsu; Osvino = SCS458 Osvino. 

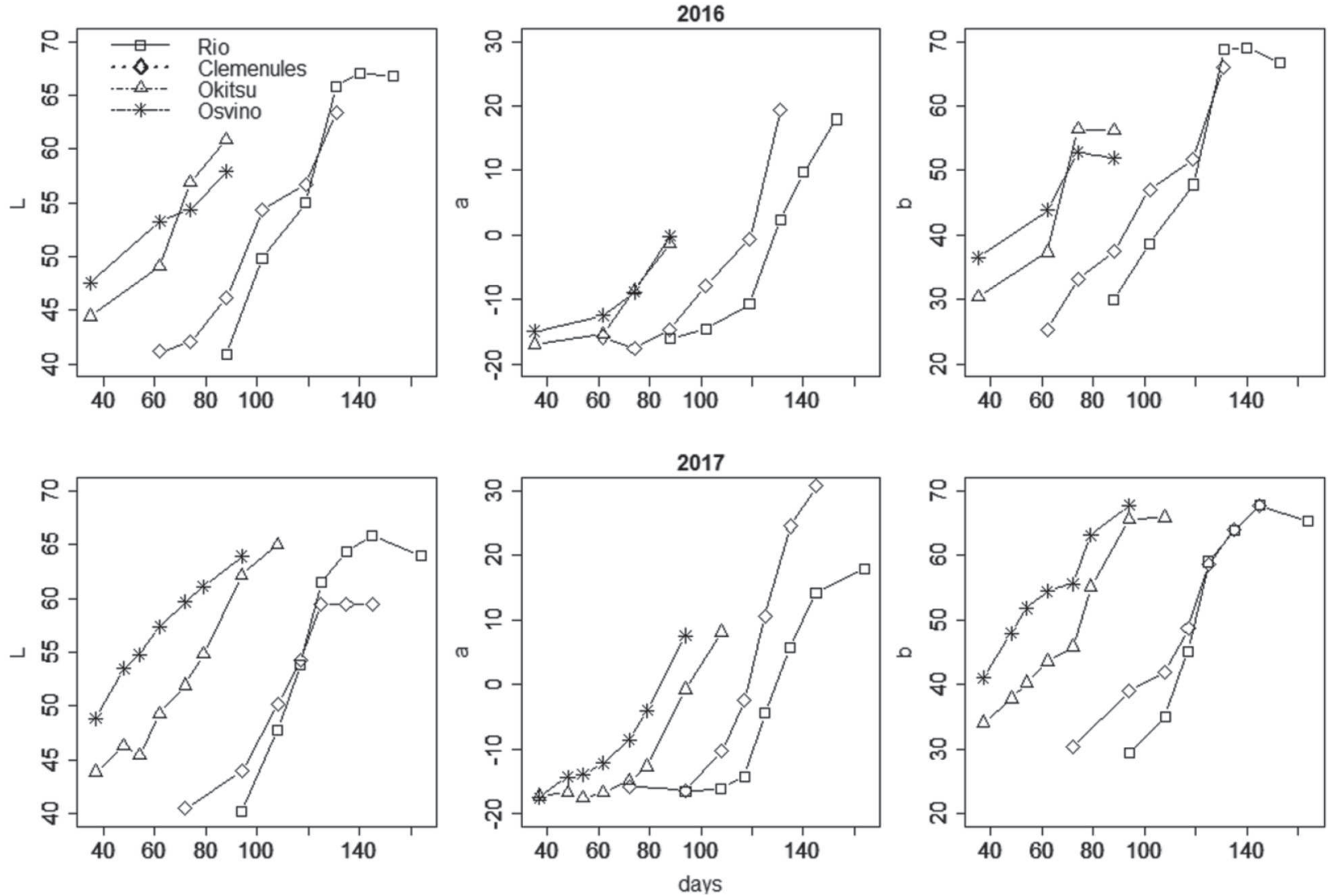

Figure 4: Temporal evolution of the parameters $L, a$ and $b$ (C.I.E.-Lab color system) in mandarin peel of four cultivars in the seasons 2016 and 2017 (mean of two rootstocks). Rio = Mexirica do Rio IAC; Okitsu = Satsuma Okitsu; Osvino = SCS458 Osvino.

RI with 'Clemenules' agree with observations from Corrientes, Argentina, and Rosário do Sul, Brazil (Malgarim et al., 2007; Rodriguez et al., 2007).

The cultivar Mexirica do Rio IAC needed more time to reach a same value of RI or CI than the others. However, when compared to the Satsumas it showed higher SS content. 'Mexirica do Rio IAC' surpassed the RI of 8.0 at $96^{\circ}$ day in 2017 , and in 2016 it had been already over the limit $(\mathrm{RI}=8.0)$ at first sample $\left(88^{\circ}\right.$ day $)$. That time, its CI was still in green range (around -15). So, as well as 'Clemenules', harvest beginning for 'Mexirica do Rio IAC' depends on its peel color. However, there is no objective $\mathrm{CI}$ to determinate harvesting time. It depends on the consumer preference, which is particular of each country or region.

'Swingle' and 'IAC 387 Carrizo' affected 'Clemenules' juice acidity in a late harvest (RI near 20) in Spain (Legua et al., 2014). With 'Satsuma Okitsu', SS and RI were influenced significantly by those rootstocks (Tazima et al., 2013). Both results disagree with the present findings. Nevertheless, other authors found no difference due to 'Swingle' and 'IAC 387 Carrizo' treatments in SS, TA, RI and juiciness of 'Satsuma Okitsu' (Tazima et al., 2014). The disagreeing observations on juice quality with same scion and rootstocks cultivars can be due to different environments and management of plants. Rootstocks have different capacities of taking water and nutrients from the soil (Toplu et al., 2012, Hussain et al., 2018) and producing growth regulators (Tworkoski \& Fazio, 2016) to supply to the canopy. The interaction of such capacities with the environment results in different responses of fruit quality. Any data on the effect of 'IAC 387 Carrizo' as a rootstock for $C$. deliciosa is available. However, no difference in juice properties was observed when the citrange 'Troyer' was compared to 'Swingle' having 'Montenegrina' (a late maturing C. deliciosa cultivar) as scion cultivar (Gonzatto, 2015), what agrees with the present findings.

\section{CONCLUSION}

The cultivars SCS458 Osvino, Satsuma Okitsu and Clemenules are earlier in maturation compared to 'Mexirica do Rio IAC'.

'SCS458 Osvino' is the most precocious in peel maturation.

The rootstocks 'Swingle' and 'IAC 387 Carrizo' do not affect fruit maturation of 'SCS458 Osvino', 'Satsuma Okitsu', 'Clemenules' nor 'Mexirica do Rio IAC'. 


\section{REFERENCES}

Albertini MV, Carcouet E, Pailly O, Gambotti C, Luro F \& Berti L (2006) Changes in organic acids and sugars during early stages of development of acidic and acidless citrus fruit. Journal of Agricultural and Food Chemistry, 54:8335-8339.

Brugnara EC (2017) Desempenho de tangerineiras jovens, de maturação precoce, enxertadas em Swingle ou Carrizo no Oeste de Santa Catarina, Brasil. Agropecuária Catarinense, 30:69-73.

Daito H (1986) Maturity and its regulation in satsuma mandarin fruit. Japan Agricultural Research Quarterly, 20:48-59.

Elzhov TV, Mullen KM, Spiess AN \& Bolker B (2016) minpack.lm: $\mathrm{R}$ Interface to the Levenberg-Marquardt Nonlinear Least-Squares Algorithm Found in MINPACK, Plus Support for Bounds. R package version 1.2-1. Available at: <https://CRAN.R-project.org/ package $=$ minpack. $1 \mathrm{~m}>$. Accessed on: February $18^{\text {th, }} 2019$.

Gonzatto MP (2015) Desempenho hortícola de tangerineiras e híbridos sobre diferentes porta-enxertos no Rio Grande do Sul. Tese de doutorado. Universidade Federal do Rio Grande do Sul, Porto Alegre. 184p.

Hussain S, Khalid MF, Saqib M, Ahmad S, Zafar W, Rao MJ, Morillon R \& Anjum MA (2018) Drought tolerance in citrus rootstocks is associated with better antioxidant defense mechanism. Acta Physiologiae Plantarum, 40:135.

IBGE - Instituto Brasileiro de Geografia e Estatística (2018) Sistema IBGE de Recuperação Automática - SIDRA. Available at: <https://sidra.ibge.gov.br/tabela/1613>. Accessed on: October $18^{\text {th }}, 2018$.

Jimenez-Cuesta M, Cuquerella J \& Martínez-Jávaga JM (1981) Determination of color index for citrus fruit degreening. Proceedings of the International Society of Citriculture, 2:750-753.

Khosravi F, Rastakhiz N, Iranmanesh B \& Olia SSSJ (2015) Determination of Organic Acids in Fruit juices by UPLC. International Journal of Life Sciences, 9:41-44.

Koller OC (1994) Citricultura: laranja, limão e tangerine. Porto Alegre, Editora Rigel. 446p.

Koller OL \& Soprano E (2013) Principais cultivares cítricos. In: Koller OL (Ed.) Citricultura Catarinense. Florianópolis, Epagri. p. $57-120$

Legua P, Forner JB, Hernándeza FCA \& Forner-Ginerb MA (2014) Total phenolics, organic acids, sugars and antioxidant activity of mandarin (Citrus clementina Hort. ex Tan.): Variation from rootstock. Scientia Horticulturae, 174:60-64.

Malgarim MB, Cantillano RFF \& Treptow RO (2007) Conservação de tangerina cv. Clemenules utilizando diferentes recobrimentos. Acta Scientiarum Agronomy, 29:75-82.

Manera FJ, Brotons JM, Conesa A \& Porras I (2013) Relation between temperature and the beginning of peel color change in grapefruit (Citrus paradisi Macf.). Scientia Horticulturae, 160:292-299.

Maro LAC, Koller OL, Mariguele KH, Brugnara EC \& Soprano E (2018) 'SCS458 Osvino': novo cultivar de tangerineira precoce com alto potencial produtivo tolerância ao frio e ausência de sementes. Agropecuária Catarinense, 31:52-55.

R Core Team (2018) R: A language and environment for statistical computing. Vienna, R Foundation for Statistical Computing. Available at: http://www.R-project.org/. Accessed on: February $18^{\text {th }}, 2019$.

Rodriguez VA, Mazza SM, Martínez GC, Alvarenga L, Píccoli AB, Ortiz ML \& Avanza MM (2007) Uso de reguladores de crecimiento para incrementar la productividad de mandarino 'Clemenules'. Revista Brasileira de Fruticultura, 29:48-56.
Santos D, Matarazzo PHM, Silva DFP, Siqueira DLD, Santos DCMS \& Lucena CC (2010) Caracterização físico-química de frutos cítricos apirênicos produzidos em Viçosa Minas Gerais. Revista Ceres, 57:393-400.

Schwarz SF (2009) Melhoramento genético e variedades. In: Koller OC (Ed.) Citricultura: cultura de tangerineiras - tecnologia de produção pós-colheita e industrialização. Porto Alegre, Rigel. p. 35-48.

Sharma RR, Singha R \& Saxena SK (2006) Characteristics of citrus fruits in relation to granulation. Scientia Horticulturae, 111:91-96.

Stenzel NMC, Neves CSVJ, Marur CJ, Scholz MBS \& Gomes JC (2006) Maturation curves and degree-days accumulation for fruits of 'Folha Murcha' orange trees. Scientia Agricola, 63:219225 .

Tazima ZH, Neves CSVJ, Yada IFU \& Leite Júnior RP (2013) Performance of 'Okitsu' Satsuma Mandarin on nine rootstocks. Scientia Agricola, 70:422-427.

Tazima ZH, Neves CSVJ, Yada IFU \& Leite Júnior RP (2014) Performance of 'Okitsu' satsuma mandarin trees on different rootstocks in Northwestern Paraná State. Semina: Ciências Agrárias, 35:2297-2308.

Toplu C, Uygur I, Kaplankýran M, Demirkeser TH \& Yýldýz E (2012) Effect of citrus rootstocks on leaf mineral composition of 'Okitsu' 'Clausellina' and 'Silverhill' mandarin cultivars. Journal of Plant Nutrition, 35:1329-1340.

Tworkoski T \& Fazio G (2016) Hormone and growth interactions of scions and size-controlling rootstocks of young apple trees. Plant Growth Regulation, 78:105-119.

Yildiz E \& Kaplankiran M (2018) Performances of 'Okitsu' and 'Clausellina' Satsuma Mandarins on Different Rootstocks in Eastern Mediterranean of Turkey. Ege Journal of Agricultural Research, 55:139-145.

Zeviani WM (2013) Parametrizações interpretáveis em modelos não lineares. Tese de doutorado. Universidade Federal de Lavras, Lavras. 146p.

Rev. Ceres, Viçosa, v. 66, n.4, p. 249-256, jul/aug, 2019 